\title{
Kepercayaan Masyarakat terhadap Penolong Persalinan di Wilayah Halmahera Utara
}

\author{
Sitti Nurhidayanti*), Ani Margawati**), Martha Irene $\left.{ }^{* *}\right)$ \\ *) Magister Promosi Kesehatan Universitas Diponegoro \\ Korespondensi : Idhaishak@yahoo.co.id \\ **) Fakultas Kesehatan Masyarakat Universitas Diponegoro Semarang
}

\begin{abstract}
ABSTRAK
AKI di Indonesia terus meningkat, SDKI 2007 menunjukkan AKI sebesar 228 per 100.000, tahun 2012 menjadi 359 per 100.000 kelahiran hidup. Salah satu faktor masih tingginya AKI karena relatif masih rendahnya pertolongan oleh tenaga kesehatan yakni hanya sebesar 55,4\%. Tujuan penelitian untuk mendeskripsikan kepercayaan masyarakat terhadap penolong persalinan di wilayah Halmahera Utara. Jenis penelitian ini adalah kualitatif. Data dikumpulkan dengan menggunakan metode FGD (Focus Group Discussion). Subjek penelitian sebanyak 26 informan yang terdiri dari $7 \mathrm{ibu}$ yang melahirkan dengan pertolongan dukun bayi, 2 orang suami, 3 orang tua, 4 tokoh masyarakat, 6 dukun bayi dan 4 orang bidan yang dipilih dengan kriteria inklusi. Analisis data menggunakan content analisis. Hasil penelitian menunjukkan bahwa informan lebih memilih dukun bayi sebagai penolong persalinan karena informan percaya dukun bayi lebih berpengalaman dalam menolong persalinan, dukun bayi juga dinilai lebih perhatian dan sabar dalam melayani pasiennya. Pemilihan dukun bayi sebagai penolong persalinan berkaitan dengan pelayanan yang diberikan dan kepercayaan masyarakat itu sendiri.
\end{abstract}

Kata Kunci: Penolong Persalinan, Kepercayaan, Dukun Bayi.

\begin{abstract}
MMR in Indonesia continues to increase, IDHS 2007 shows MMR of 228 per 100,000 in 2012 to 359 per 100,000 live births. One factor is still high maternal mortality rate due to relatively low relief by the health provider only by 55.4\%. The aim of research to describe people's confidence in birth attendants in the region of North Halmahera. This type of research is qualitative. Data were collected using FGD (Focus Group Discussion). Research subjects were 26 informants consisted of 7 mothers who gave birth with the help of TBAs, 2 husbands, 3 parents, 4 community leaders, 6 TBAs and 4 midwives chosen by the inclusion criteria. Analysis of data using content analysis. The results showed that the informant preferring TBAs as birth attendants because informants believe TBAs are more experienced in attending births, TBAs are also considered more attention and patience in serving patients. Selection of TBAs as birth attendants associated with the services provided and the trust of society itself. Keywords: Delivery Helper, Confidence, TBAs.
\end{abstract}

\section{PENDAHULUAN}

Angka Kematian Ibu (AKI) dewasa ini masih tinggi di Indonesia dibandingkan dengan negara-negara ASEAN lainnya. Angka Kematian Ibu (AKI) terus meningkat, berdasarkan SDKI 2007 Angka
Kematian Ibu sebesar 228 per 100.000 kelahiran hidup meningkat pada tahun 2012 menjadi 359 per 100.000 kelahiran hidup. Padahal sesuai MDGs, pada tahun 2015 Indonesia harus mampu menurunkan 
AKI menjadi 102 per 100.000 kelahiran hidup (Saputra, 2014).

Sementara Angka Kematian Bayi (AKB) masih cukup tinggi meskipun mengalami penurunan namun sangat lambat. AKB berdasarkan SDKI 2007 sebesar 34 per 1000 kelahiran hidup dan tahun 2012 turun menjadi 32 per 1000 kelahiran hidup. Target MDGs pada tahun 2015 Indonesia harus mampu menurunkan AKB menjadi 23 per 1000 kelahiran hidup (SDKI, 2007).

Banyak hal yang menyebabkan masih tingginya Angka Kematian Ibu di Indonesia mulai dari budaya sampai dengan permasalahan akses pelayanan kesehatan. Sebesar 90\% kematian ibu disebabkan karena sebab yang secara langsung berkaitan dengan kondisi kehamilan, persalinan dan nifas, seperti perdarahan, eklamsia, partus lama maupun infeksi.

Salah satu faktor tingginya AKI di Indonesia adalah karena relatif masih rendahnya cakupan pertolongan oleh tenaga kesehatan. Rendahnya pendidikan di masyarakat, budaya dan ekonomi menjadikan sebagian masyarakat memilih bersalin pada tenaga non kesehatan (dukun). Hasil riset kesehatan dasar (Riskesdas) juga menunjukkan bahwa persalinan oleh tenaga kesehatan di fasilitas kesehatan baru mencapai 55,4\% . hal ini menunjukkan bahwa sekitar 43,2\% persalinan masih ditolong oleh dukun (Riskesdas, 2010).

Pertolongan persalinan oleh tenaga kesehatan merupakan strategi untuk menangani masalah kesehatan ibu dan anak di Indonesia. Kemampuan dan keterampilan penolong persalinan sangat mempengaruhi terjadinya kematian ibu maupun bayi. Menurut hasil penelitian dari 97 negara bahwa ada korelasi yang signifikan antara pertolongan persalinan dengan kematian ibu. Semakin tinggi cakupan persalinan oleh tenaga kesehatan di suatu wilayah akan diikuti penurunan kematian ibu di wilayah tersebut (Depkes RI, 2008).

Pertolongan persalinan oleh non tenaga kesehatan (dukun bayi) menimbulkan masalah karena mereka bekerja tidak berdasarkan ilmiah, pengetahuan mereka tentang fisiologi dan patologi pada persalinan juga masih sangat terbatas sehingga mereka tidak mengenal tindakan antiseptik yang dapat mengakibatkan tingginya angka kematian ibu dan bayi. Pertolongan persalinan oleh dukun menimbulkan berbagai masalah dan penyebab tingginya angka kesakitan dan kematian ibu dan bayi baru lahir (Maisya, 2006).

Propinsi Maluku Utara memiliki kasus kematian ibu yang masih cukup tinggi. Berdasarkan laporan dinas kesehatan, kasus kematian ibu pada tahun 
2010 tercatat 42 kasus kematian meningkat pada tahun 2011 sebanyak 92 kasus, tahun 2012 turun menjadi 89 kasus, dan pada tahun 2013 menjadi 90 kasus kematian. Untuk kasus kematian bayi di propinsi Maluku Utara terus meningkat, pada tahun 2011 sebesar 250 kasus meningkat pada tahun 2012 sebesar 276 kasus dan pada tahun 2013 menjadi 280 kasus kematian (Dinkes Malut, 2012)

Di kabupaten Halmahera Utara (Halut) yakni salah satu kabupaten yang berada di propinsi Maluku Utara, kasus kematian ibu yang dilaporkan pada tahun 2010 sebesar 4 kasus kematian, 2011 meningkat menjadi 10 kasus, tahun 2012 turun menjadi 8 kasus dan pada tahun 2013 menjadi 9 kasus kematian ibu. Untuk kasus kematian bayi dari tahun ke tahun terus mengalami peningkatan, dari 62 kasus pada tahun 2010, meningkat 77 kasus di tahun 2011 dan 81 kasus kematian di tahun 2012 dan pada tahun 2013 meningkat menjadi 83 kasus kematian bayi (Dinkes Halut, 2012).

Dari 62 kasus kematian bayi tahun 2010, ada 39.8\% kasus kematian yang persalinannya di tolong oleh dukun bayi, tahun 2011 ada $41.5 \%$ yang di tolong dukun bayi dari 77 kasus kematian, dan pada tahun 2012 dan 2013 dari 83 kasus kematian ada $38 \%$ kasus kematian yang persalinannya di tolong oleh dukun bayi. (Dinkes Halut, 2012).
Untuk jumlah bidan di kabupaten Halmahera Utara terus mengalami peningkatan dari tahun ke tahun, pada tahun 2010 jumlah bidan sebesar 135 orang meningkat pada tahun 2011 sebesar 171 orang dan pada tahun 2012 dan 2013 menjadi 190 orang bidan. jumlah dukun bayi juga terus mengalami peningkatan. Berdasarkan data dinas kesehatan tercatat pada tahun 2010 jumlah dukun sebanyak 319 dukun bayi, meningkat pada tahun 2011 dan 2012 menjadi 332 dukun dan pada tahun 2013 menjadi 335 dukun bayi. (Profil kesehatan Halut, 2012).

Sebanyak $30 \%$ masyarakat di kabupaten Halmahera Utara khususnya di kecamatan Tobelo Utara desa Tolonuo, desa Kokota Jaya dan desa Ruko persalinannya masih di bantu oleh dukun bayi, meskipun telah ada program jampersal yang menggratiskan biaya persalinan, keadaan ini masih jauh dari target Standar Pelayanan Minimal (SPM) bidang kesehatan, dimana persalinan oleh non tenaga kesehatan harusnya tidak lebih dari 10\%. (Profil kesehatan Halut, 2012). Penelitian ini akan mendeskripsikan kepercayaan masyarakat terhadap penolong persalinan di wilayah Halmahera Utara.

\section{METODE}

Metode penelitian yang digunakan adalah metode kualitatif yang disajikan 
secara deskriptif. Pengumpulan data dilakukan dengan cara diskusi kelompok terarah. Populasi dalam penelitian ini adalah seluruh ibu yang memiliki riwayat pernah melahirkan di dukun bayi setelah adanya program jampersal, keluarga, tokoh masyarakat setempat, dukun bayi dan bidan yang berada di kabupaten Halmahera Utara khususnya yang berada di desa Kokota Jaya dan desa Tolonuo. Sampel penelitian sebanyak 26 informan yang terdiri dari 7 ibu yang melahirkan dengan pertolongan dukun bayi, 2 orang suami, 3 orang tua, 4 tokoh masyarakat, 6 dukun bayi dan 4 orang bidan yang dipilih dengan kriteria inklusi. Analisis data menggunakan content analisis.

\section{HASIL DAN PEMBAHASAN}

\section{Gambaran Umum Lokasi Penelitian}

Kecamatan Tobelo Utara merupakan salah satu kecamatan yang berada di kabupaten Halmahera Utara, luas wilayah Tobelo Utara sebesar 100,40 km². Jumlah penduduknya sebesar 10.777 jiwa. Tobelo Utara terdiri dari sepuluh (10) desa, tiga diantaranya adalah desa Tolonuo, desa Kokota Jaya dan desa Ruko yang mana merupakan desa yang masih tergolong tinggi persalinannya menggunakan bantuan dukun bayi. Daerah tempat penelitian yaitu di desa Tolonuo dan desa Kokota Jaya. (BPS Halut, 2012).

\section{Karakteristik Informan}

a. Desa Kokota Jaya

Informan dalam penelitian ini ratarata berumur empat puluh empat (44) tahun, usia termuda dua puluh satu (21) tahun dan yang paling tua berusia enam puluh tiga (63) tahun. Sebagian besar dari informan berjenis kelamin perempuan yang berjumlah sepuluh (10) orang, sisanya laki-laki yang berjumlah tiga (3) orang.

Setengah dari informan memiliki pendidikan Sekolah Dasar (SD) yaitu sebanyak enam (6) orang, sisanya berpendidikan Sekolah Menengah Pertama (SMP) berjumlah dua (2) orang, Sekolah Menengah Atas (SMA) berjumlah dua (2) orang, D3 sebanyak dua (2) orang dan Sarjana satu (1) orang. 
Tabel 1. Karakteristik Informan Desa Kokota Jaya

\begin{tabular}{|c|c|c|c|c|c|c|}
\hline No & $\begin{array}{c}\text { Insial } \\
\text { Peserta }\end{array}$ & $\begin{array}{c}\text { Jenis } \\
\text { Kelamin }\end{array}$ & Umur & Pendidikan & Pekerjaan & Keterangan \\
\hline 1 & Sw & $\mathrm{P}$ & 25 thn & SMA & IRT & Ibu bersalin \\
\hline 2 & $\mathrm{Nn}$ & $\mathrm{P}$ & 21 thn & SMP & Pedagang & Ibu bersalin \\
\hline 3 & $\mathrm{Hi}$ & $\mathrm{P}$ & 35 thn & $\mathrm{SD}$ & IRT & Ibu bersalin \\
\hline 4 & $\mathrm{Mm}$ & $\mathrm{P}$ & 53 thn & SD & Pedagang & Orang Tua \\
\hline 5 & $\mathrm{Mh}$ & $\mathrm{P}$ & 57 thn & SD & IRT & Orang Tua \\
\hline 6 & $\mathrm{Sn}$ & $\mathrm{L}$ & 40 thn & SMP & Nelayan & Suami \\
\hline 7 & $\mathrm{Ri}$ & $\mathrm{L}$ & 50 thn & S1 & PNS & Tokoh Masy. \\
\hline 8 & Ih & $\mathrm{L}$ & 55 thn & SMA & Guru & Tokoh Masy. \\
\hline 9 & $\mathrm{Li}$ & $\mathrm{P}$ & 63 thn & $\mathrm{SD}$ & Biang & Dukun Bayi \\
\hline 10 & $\mathrm{Ha}$ & $\mathrm{P}$ & 60 thn & SD & Biang & Dukun Bayi \\
\hline 11 & $\mathrm{Nh}$ & $\mathrm{P}$ & 55 thn & SD & Biang & Dukun Bayi \\
\hline 12 & $\mathrm{Hh}$ & $\mathrm{P}$ & 30 thn & D3 & Bidan & Bidan \\
\hline 13 & $\mathrm{Sa}$ & $\mathrm{P}$ & 27 thn & D3 & Bidan & Bidan \\
\hline
\end{tabular}

\section{b.Desa Tolonuo}

Informan dalam penelitian ini ratarata berumur empat puluh empat (41) tahun, usia termuda dua puluh satu (21) tahun dan yang paling tua berusia enam puluh (60) tahun. Sebagian besar dari informan berjenis kelamin perempuan yang berjumlah sepuluh (10) orang, sisanya laki-laki yang berjumlah tiga (3) orang.
Setengah dari informan memiliki pendidikan Sekolah Dasar (SD) yaitu sebanyak enam (6) orang, sisanya berpendidikan Sekolah Menengah Pertama (SMP) berjumlah dua (2) orang, Sekolah Menengah Atas (SMA) berjumlah tiga (3) orang, D3 sebanyak dua (2) orang.

Tabel 2. Karakteristik Informan Desa Tolonuo

\begin{tabular}{|c|l|c|c|c|c|l|}
\hline No & \multicolumn{1}{|c|}{ Nama } & $\begin{array}{c}\text { Jenis } \\
\text { Kelamin }\end{array}$ & Umur & Pendidikan & Pekerjaan & Keterangan \\
\hline 1 & $\mathrm{Na}$ & $\mathrm{P}$ & $28 \mathrm{thn}$ & SMP & IRT & Ibu bersalin \\
\hline 2 & $\mathrm{Ad}$ & $\mathrm{P}$ & 22 thn & SD & IRT & Ibu bersalin \\
\hline 3 & $\mathrm{Aa}$ & $\mathrm{P}$ & 21 thn & SMA & Petani & Ibu bersalin \\
\hline 4 & $\mathrm{Ma}$ & $\mathrm{P}$ & 35 thn & SMP & IRT & Ibu bersalin \\
\hline 5 & $\mathrm{Hm}$ & $\mathrm{P}$ & 56 thn & SD & IRT & Orang Tua \\
\hline 6 & $\mathrm{Rs}$ & $\mathrm{L}$ & 40 thn & SD & Buruh & Suami \\
\hline 7 & $\mathrm{Hs}$. & $\mathrm{L}$ & 50 thn & SMA & Nelayan & Tokoh Masy. \\
\hline 8 & $\mathrm{Mf}$ & $\mathrm{L}$ & 56 thn & SMA & swasta & Tokoh Masy. \\
\hline 9 & Ys & $\mathrm{P}$ & 59 thn & SD & Biang & Dukun Bayi \\
\hline 10 & $\mathrm{Ft}$ & $\mathrm{P}$ & 53 thn & SD & Biang & Dukun Bayi \\
\hline 11 & $\mathrm{Ja}$ & $\mathrm{P}$ & 60 thn & SD & Biang & Dukun Bayi \\
\hline 12 & $\mathrm{Nl}$ & $\mathrm{P}$ & 30 thn & D3 & Bidan & Bidan \\
\hline 13 & $\mathrm{Hn}$ & $\mathrm{P}$ & 28 thn & D3 & Bidan & Bidan \\
\hline
\end{tabular}


Pengetahuan terhadap Kehamilan dan Persalinan

Hasil temuan penelitian dari dua desa yaitu desa Kokota Jaya dan desa Tolonuo menunjukkan bahwa masyarakat jarang melakukan pemeriksaan kehamilan ke petugas kesehatan. Informan mengungkapkan bahwa mereka hanya akan memeriksakan kehamilannya apabila terjadi hal-hal yang menurut mereka mengganggu aktivitas sehari-hari, seperti adanya keluhan ketika hamil seperti mual atau muntah yang berlebihan, dan sesak napas.

\section{"...Kalau kami disini jarang pergi periksa} hamil alasannya karena tidak ada keluhan, kecuali kalau ada keluhan saja seperti muntah-muntah, rasa sesak nafas atau kaki bengkak baru pergi periksa, kami disini tidak terlalu pusing (peduli) dengan hal tersebut (periksa hamil)...” (Ad.P.22th)

Rendahnya tingkat pendidikan dapat berpengaruh terhadap pengetahuan sikap dan perilaku masyarakat, khususnya yang berkaitan dengan kehamilan dan persalinan (Notoatmodjo, 2010). Merujuk pada teori sosial kognitif, pengetahuan serta pengalaman seseorang menjadikan orang tersebut dapat belajar dari lingkungan sosial, sehingga perilaku yang akan dilakukannya sangat bergantung pada sikap yang dibentuk dari pengetahuan dan pengalamannya.

Pengetahuan dan pengalaman dari masyarakat yang menganggap kehamilan dan persalinan merupakan proses alamiah yang akan dialami oleh seorang wanita sebagai sebuah kejadian yang wajar dan tidak perlu menerima perhatian khusus berdampak pada tidak adanya perhatian terhadap ibu hamil seperti tidak melakukan pemeriksaan rutin saat kehamilan, tidak memperhatikan asupan gizi, dan pemilihan penolong persalinan yang kurang tepat.

Sikap negatif dan rendahnya kepedulian terhadap ibu hamil ini disebabkan informan tidak memahami betapa pentingnya manfaat pemeriksaan kehamilan, serta resiko yang akan terjadi pada saat melahirkan. Selain itu, pemeriksaan kehamilan secara rutin dan memperhatikan asupan gizi yang baik sangat berpengaruh pada tumbuh kembang anak.

Terdapat beberapa hal yang berhubungan dengan perilaku seseorang dalam kaitannya dengan pelayanan antenatal. Pertama, latar belakang (dapat berupa sosial budaya) yang mempengaruhi pemeriksaan kehamilan. Kedua perilaku ibu hamil yang dipengaruhi oleh pengetahuan dan kepercayaan tentang manfaat yang akan diperoleh dalam memeriksakan kehamilannya. Ketiga, ketersediaan sarana 
dan pelayanan fasilitas kesehatan yang akan membantu ibu hamil untuk memeriksakan kehamilannya. Keempat, adanya perkataan dari ibu hamil lainnya yang mengatakan bahwa mereka mengalami kesulitan dalam proses persalinan. (Nuraeni, 2012).

Suprapto dalam Anike menyatakan bahwa faktor dominan yang berhubungan dengan pemilihan penolong persalinan adalah pendidikan. Ibu yang memiliki pendidikan rendah cenderung memilih tenaga non kesehatan (dukun bayi) sebagai penolong persalinannya dibandingkan dengan ibu yang berpendidikan tinggi. (Anike, 2007).

Mesters juga menyatakan bahwa semakin tinggi tingkat pendidikan seseorang, maka semakin tinggi kualitas hidup yang dimiliki orang tersebut. Lanjutnya Ia mengatakan bahwa kualitas hidup yang tinggi dari seseorang maka orang tersebut lebih sadar akan kesehatan dan memiliki banyak pengetahuan yang unggul dibandingkan dengan orang yang pendidikannya rendah. (Mesters, 2014).

\section{Persepsi Terhadap Penolong Persalinan}

Dari hasil penelitian menunjukkan bahwa Ibu yang hendak bersalin lebih merasa nyaman bila persalinannya dilakukan di rumah dan dibantu oleh dukun bayi, hal ini dikarenakan tingginya kepercayaan masyarakat kepada dukun bayi dan kenyamanan melakukan persalinan dirumah. Dukun bayi juga dinilai lebih perhatian, lebih sabar, ramah dan penuh kelembutan dalam melayani ibu bersalin yang membutuhkan pertolongan sehingga membuat para ibu lebih merasa nyaman.

"... di biang saya rasa lebih tenang \& nyaman karena mereka sangat perhatian, sabar dan tidak marah-marah, mereka mengelus-elus perut saya, mereka kasih tenang sama saya, katanya harus sabar, terus berdoa dan tidak usah terlalu khawatir..." (Sw.P.25th)

Dukun bayi juga dinilai lebih berpengalaman. Informan mengungkapkan bahwa mereka percaya dengan dukun bayi karena dukun bayi sudah bertahun-tahun menolong persalinan dan tidak terjadi halhal yang membahayakan atau merugikan jiwa informan. Selain itu, Dukun bayi juga dengan sabar bersedia menunggui ibu bersalin sampai ibu melahirkan bahkan juga bersedia merawat ibu yang melahirkan hingga tali pusat sang bayi lepas. Dukun bayi juga dapat membersihkan ari-ari serta dapat memperbaiki posisi bayi di dalam perut ibu jika belum benar atau posisinya turun. Pelayanan seperti ini yang tidak didapatkan ibu di bidan.

"... dan kalau dipanggil langsung datang, mereka juga bersedia menunggu dari sakit perut hingga bersalin bahkan mereka juga mau merawat saya dan bayi hingga tali 
pusat bayi lepas, biang juga mau membersihkan dodomi (ari-ari) dan kalau perut kita turun maka akan dibetulkan posisinya..." (Sw.P.25th)

Dari hasil penelitian, informan juga mengungkapkan bahwa pelayanan oleh dukun bayi dan bidan dirasakan berbeda. Menurut informan, jika dukun bayi lebih perhatian dalam menangani pasiennya. Lain halnya dengan bidan yang kurang perhatian dan kurang ramah dalam menghadapi pasiennya. Selain itu bidan juga jarang berada di tempat yang membuat bidan kurang berinteraksi dengan masyarakat sehingga mereka terkesan kurang ramah di mata masyarakat.

Pandangan terhadap dukun bayi berdasarkan pendapat dari tokoh masyarakat (ustad, orang yang dituakan atau yang berpengaruh di desa Kokota Jaya dan Tolonuo) adalah pada umumnya para dukun bayi akan segera datang jika diminta untuk menolong persalinan, meskipun tengah malam bahkan dengan cuaca yang ekstrim sekalipun dukun bayi tersebut akan segera datang untuk menolong persalinan.

Pendapat lainnya yang juga diungkapkan oleh seorang informan dari desa Tolonuo, menurutnya bidan yang bertugas di tempatnya masih muda dan belum menikah sehingga belum berpengalaman dalam hal bersalin dan menolong persalinan. Ada juga sebagian informan yang menggunakan jasa bidan dalam membantu persalinan, namun informan juga tetap memanggil dukun bayi untuk mendampingi bidan dalam menolong persalinan mereka. Sebagian besar informan mengungkapkan bahwa jika bersalin didampingi dukun bayi maka mereka merasa lebih kuat.

Keberadaan bidan muda meskipun berasal dari masyarakat setempat, tidak serta merta diterima di lingkungannya. Bidan muda dengan usia yang masih sangat muda, mereka termasuk ke dalam kriteria bidan yang kurang berpengalaman, hal itu ditambah dengan statusnya yang belum menikah dan belum berpengalaman untuk hamil atau merawat bayi. Lebih jauh informan mengungkapkan alasan bahwa dalam memilih penolong persalinan, ingin memilih yang berpengalaman, baik pengalaman dalam persalinan ataupun pengalaman dalam menolong persalinan, bukan oleh penolong persalinan yang belum pernah melewati proses persalinan, karena hal ini berhubungan dengan keselamatan ibu dan bayinya.

Kepercayaan adalah keyakinan dalam diri individu dalam kondisi yang rentan bahwa orang yang dipercayai (trustee) akan menunjukkan perilaku yang konsisten, jujur, bisa dipercaya, perhatian terhadap kepentingan orang yang mempercayai (truster), mengupayakan yang terbaik bagi truster melalui sikap menerima, 
mendukung, sharing, dan bekerja sama. (Mayer dkk, 1995). Sejalan dengan teori tersebut, dari hasil penelitian ini, sikap yang ditunjukkan oleh dukun bayi seperti memberi perhatian yang lebih, sabar, ramah dan sikap saling percaya merupakan faktorfaktor yang membuat masyarakat pergi ke dukun bayi untuk melakukan persalinan.

Hasil penelitian oleh Nuraeni juga menunjukkan hal yang sama yakni perasaan aman dan nyaman juga dirasakan oleh ibu setiap ditolong oleh dukun bayi, kesiap siagaan dukun bayi telah membuat sebagian informan merasa senang karena dukun bayi selalu ada saat dibutuhkan, sehingga sebagian besar ibu memiliki kecendurungan merencanakan kembali ditolong oleh dukun bayi saat persalinan. (Nuraeni, 2012).

Hasil penelitian lain oleh Triratnawati menunjukan bahwa dukun bayi dianggap mampu menentramkan ibu hamil yang akan melahirkan beserta keluarganya. Hal tersebut karena dukun bayi bersedia menunggu saat persalinan hingga berjamjam bahkan lebih. Jika ibu hamil merasakan badannya capai menjelang persalinan, dukun bayi tersebut segera memijat dan memberi nasehat agar ibu hamil sabar dan tabah dalam menghadapi persalinan. Berbeda dengan bidan yang memiliki jam kerja yang terbatas sehingga waktu komunikasi dan interaksi antara bidan dan pasien sangat terbatas, membuat bidan hanya bisa melakukan hal-hal yang memang hanya untuk membantu sang bayi lahir dan ibunya selamat. (Triratnawati, 1995).

Menurut Taylor, Bannet \& Murphy pengaruh kognitif berkaitan dengan keyakinan atau kepercayaan diri seseorang dalam berperilaku. Keyakinan dalam melakukan suatu perilaku akan memberikan pengaruh dalam melakukan suatu tindakan tertentu. Dalam teori sosial kognitif, faktor internal maupun eksternal dianggap penting. Peristiwa di lingkungan, faktor-faktor personal, dan perilaku dilihat saling berinteraksi dalam proses belajar. Faktorfaktor personal (keyakinan, ekspektasi, sikap, rasa nyaman dan pengetahuan), lingkungan fisik dan sosial (sumber daya, konsekuensi tindakan, orang lain, dan setting fisik) semuanya saling mempengaruhi dan dipengaruhi. (Santrock, 2010).

Alasan lain masyarakat masih mempercayakan persalinan mereka kepada dukun bayi karena dukun bayi merupakan seorang yang berpengaruh di masyarakat yang diyakini dan dipercaya mempunyai keterampilan dan kemampuan untuk menolong persalinan. Kepercayaan seseorang tergantung pada pengalaman dari orang itu sendiri, dukun bayi dinilai berpengalaman karena sudah sering menolong persalinan. Dukun bayi juga pada umumnya adalah seseorang yang sudah lanjut usia, sehingga mengerti bagaimana cara menenangkan ibu yang sedang hamil 
ataupun menjelang persalinan, mereka biasanya mengatakan hal-hal yang menenangkan yang kemudian bisa menguatkan sang ibu hamil dan keluarga.

Dalam kajian kesehatan ibu dan anak (KIA) menyebutkan bahwa dukun bayi dianggap penting semenjak masa kehamilan hingga pascakelahiran, bukan hanya terkait dengan kebutuhan fisik perempuan, tetapi juga kebutuhan mental dan spiritiual ibu sebagai anggota komunitas yang sehat. (Hermawati, 2012).

Hasil penelitian oleh Astuti juga menunjukan bahwa ibu yang memilih dukun sebagai penolong persalinan mengungkapkan alasan mereka bahwa sudah beberapa kali semua keluarga dan juga masyarakat sekitarnya bersalin dengan dukun dan hasilnya aman dan lebih mudah serta yang paling penting kondisi bayi lahir dengan selamat dan sehat. (Astuti, 2013).

Faktor yang juga ikut mempengaruhi kepercayaan masyarakat terhadap dukun bayi adalah kepercayaan diri/ keyakinan (self efficacy) serta kemampuan dari dukun bayi itu sendiri dalam menolong persalinan. Dalam teori sosial kognitif menurut Bandura self efficacy merupakan faktor kunci sumber tindakan manusia (human agency), apa yang orang pikirkan, percaya, dan rasakan mempengaruhi bagaimana mereka bertindak. (Mukhid, 2009). Selain itu, self efficacy yang tinggi dapat meningkatkan kinerja seseorang. (Harrison dkk, 1997).

Peneliti menemukan ada kaitan antara uraian teori diatas dengan hasil temuan peneliti, dimana dukun bayi sebagai orang yang membantu persalinan mempunyai self efficacy/ kepercayaan diri yang tinggi. Hal ini di dukung dengan pengalaman dukun bayi yang sudah sering menolong persalinan, kepercayaan diri yang tinggi, banyaknya orang yang percaya dan banyaknya dukun bayi lain yang juga menolong persalinan.

Hasil ini sejalan dengan teori sosial kognitif oleh Bandura yang dikutip oleh Mukhid. (Mukhid, 2009). Menurut Bandura terdapat 4 sumber utama yang mempengaruhi self efficacy, yaitu penguasaan atau pengalaman yang menetap, pengalaman yang dirasakan sendiri, bujukan sosial, dan keadaan psikologis atau emosi yang dapat dijelaskan dibawah ini.

Pertama, penguasaan atau pengalaman yang menetap dapat dilihat dari peristiwa masa lalu atas kesuksesan dan atau kegagalan yang dirasakan sebagai faktor terpenting pembentuk self efficacy seseorang. Pengalaman menetap yang peneliti lihat disini adalah pengalaman masa lalu dari para dukun bayi tersebut yang mampu membantu persalinan dengan selamat. Kedua, pengalaman yang juga dirasakan sendiri oleh dukun bayi yang sudah berulang kali menolong persalinan 
hingga saat ini. Dalam proses perawatan dan pertolongan persalinan tidak ada masalah atau mengakibatkan terjadinya sesuatu yang buruk terhadap informan sehingga informan masih mempercayakan proses kehamilan dan persalinan mereka ditangani langsung oleh dukun bayi.

Ketiga, bujukan sosial. Informan dihadapkan pada lingkungan, baik lingkungan keluarga maupun lingkungan masyarakat yang mana kebanyakan dari masyarakat yang masih membutuhkan serta menggunakan jasa dukun bayi dalam membantu persalinan sehingga secara tidak langsung "bujukan sosial" tersebut dapat mempengaruhi si informan dalam berperilaku, yakni masih mau menolong persalinan. Penelitian ini mendukung temuan dari Anderson \& Wojcik (Anderson, 1997) yang mengatakan bahwa dukungan sosial dari keluarga berpengaruh terhadap self efficacy seseorang dan berpengaruh terhadap keputusan yang diambil oleh orang tersebut. Sementara temuan lain oleh Shoji dan Benight (Shoji dkk, 2014) dukungan sosial dan self efficacy dapat mengurangi trauma dan stress.

Faktor yang keempat yakni keadaan psikologis atau emosi termasuk didalamnya adalah perasaan. Perasaan positif seperti rasa senang karena bisa membantu orang lain dalam persalinan sehingga ada kepuasaan tersendiri yang dirasakan oleh dukun bayi tersebut.

\section{Budaya}

Persepsi serta kepercayaan masyarakat pada dukun bayi yang sudah berlangsung turun temurun masih sangat kuat. Peran dukun bayi masih sangat dipercayai dapat menolong persalinan meskipun terdapat bidan di kedua desa ini dan jumlahnya selalu meningkat dari tahun ke tahun. Faktor budaya yang dikemukakan oleh informan adalah dukun bayi tidak saja menangani proses kelahiran, tetapi menangani jauh hari sebelum dan juga sesudah proses persalinan. Setelah persalinan, dukun bayi bahkan masih menangani hingga bayi berumur 44 hari. Dukun bayi memiliki peran penting bagi kelangsungan keluarga dan masyarakat, ia diberikan kepercayaan penuh oleh ibu melahirkan dan seluruh anggota keluarganya.

Dalam hal praktek perawatan selama masa nifas (setelah ibu melahirkan sampai dengan sekitar 44 hari) dukun bayi memberikan ramuan (rorano), dukun bayi juga memberikan perawatan baik terhadap ibu maupun pada bayi seperti pijat, dan menghangatkan tubuh di dekat api atau yang di sebut baraho untuk mengembalikan kebugaran tubuh setelah bersalin yang sudah menjadi kebiasaan masyarakat setempat oleh karena itu tidak mengherankan bila masyarakat masih tetap menggunakan jasa dukun bayi. 
"...kebiasaan disini jika ibu selesai bersalin maka akan di rawat oleh biang kampung, ibu diberi rorano, dimandikan bayinya, menghangatkan tubuh, belum boleh memegang pisau dan makanannya juga diatur oleh biang..." (Mh.P.57th)

Tradisi atau kebiasaan-kebiasaan tersebut setelah melahirkan dianggap masyarakat sebagai sesuatu yang harus didapatkan oleh ibu hamil maupun ibu nifas untuk memulihkan kembali kondisi ibu pasca persalinan. Terutama untuk ibu hamil yang pertama kali melahirkan. Sementara ibu hamil yang melahirkan di tenaga kesehatan/ bidan tidak mendapatkan pelayanan seperti itu karena bidan tidak memiliki keterampilan tersebut, bidan juga tidak mempunyai waktu sehingga ibu hamil yang mempunyai keyakinan pentingnya minum ramuan (rorano), pijat, menghangatkan tubuh dan ritual lainya akan lebih memilih dukun bayi sebagai penolong persalinan.

Hasil penelitian juga menunjukkan bahwa informan menilai dukun bayi piawai dalam memperbaiki posisi bayi jika belum benar posisinya dengan cara memijat perut ibu. Kebanyakan masyarakat di desa Kokota Jaya dan Tolonuo masih percaya jika perut ibu hamil turun maka harus dibetulkan dengan pemijatan di bagian perut. Namun, menurut para ahli kandungan, pijatan di perut bisa membahayakan janin. Plasenta yang melekat di rahim bisa lepas akibat pijatan. Jika hal itu terjadi maka bisa membahayakan janin, bahkan bisa menyebabkan kematian janin dalam rahim (IUFD/ Intra Uterine Fetal Death). (Hermawati, 2012).

Terdapat beberapa hal menarik dalam penelitian ini yaitu dukun bayi tetap dipanggil untuk melihat keadaan ibu hamil meskipun telah diputuskan untuk memakai bidan dalam menolong persalinan, terutama pada ibu hamil pertama kali. Pemanggilan dukun bayi untuk melihat kondisi ibu hamil merupakan budaya yang sulit ditinggalkan walaupun dalam persalinannya dibantu oleh bidan. Hal ini menunjukkan bahwa masyarakat belum sepenuhnya mempercayai bidan sebagai penolong persalinan mereka. Letak keistimewaan dari dukun bayi, terletak pada ritual-ritual seperti pemberian rorano, baraho dan pembacaan doa-doa.

Dalam penelitian ini, peneliti menemukan bahwa diantara dukun bayi dan bidan sama-sama mempunyai sisi negatif dan positifnya. Sisi negatif dari memilih dukun bayi sebagai penolong persalinan adalah karena dukun bayi memiliki keterbatasan pengetahuan tentang bahaya dalam menangani ibu hamil. Sementara untuk sisi positif dari memilih dukun bayi sebagai penolong persalinan adalah dukun bayi pada umumnya tidak menentukan berapa besar biaya yang harus dibayar oleh 
sang ibu hamil, dukun bayi juga bisa dipanggil ke rumah untuk membantu persalinan, dukun bayi lebih perhatian serta lebih sabar dan berpengalaman dalam menolong persalinan, dukun bayi mempunyai banyak waktu sehingga dapat menemani ibu sebelum dan setelah persalinan.

Untuk bidan sendiri, sisi negatifnya adalah, kurang ramah dalam membantu persalinan dan jarang berada ditempat. Sementara sisi positifnya adalah pada umumnya bidan sudah memiliki pengetahuan bagaimana menangani bayi dan ibunya. Namun dibalik semua itu sebenarnya keberadan dukun bayi dan bidan sama-sama dibutuhkan oleh masyarakat terutama oleh ibu hamil.

Memahami kebutuhan dan keinginan masyarakat adalah hal penting yang mempengaruhi kepuasan masyarakat. Masyarakat yang puas merupakan aset yang sangat berharga karena apabila masyarakat merasa puas mereka akan terus melakukan pemakaian terhadap jasa pilihannya, tetapi jika masyarakat merasa tidak puas mereka akan memberitahukan dua kali lebih hebat kepada orang lain tentang pengalaman buruknya.

\section{SIMPULAN}

Kepercayaan masyarakat terhadap penolong persalinan khususnya dukun bayi dipengaruhi oleh beberapa faktor diantaranya faktor pengetahuan, dimana faktor pengetahuan dipengaruhi oleh tingkat pendidikan masyarakatnya. Kebanyakan masyarakat di desa Kokota jaya dan desa Tolonuo berpendidikan rendah sehingga jarang melakukan pemeriksaan kehamilan ke petugas kesehatan karena tidak mengetahui manfaat pelayanan ante natal selama kehamilan. Faktor yang kedua adalah persepsi terhadap penolong persalinan. Masyarakat lebih suka melahirkan di rumah dan menggunakan jasa dukun bayi karena dukun bayi dinilai lebih perhatian dan sabar serta berpengalaman dan cekatan dalam melayani ibu bersalin yang membutuhkan pertolongan, sehingga membuat para ibu merasa nyaman. Faktor yang ketiga adalah faktor budaya. Kebiasaan melahirkan yang dibantu oleh dukun bayi sudah turun temurun dari orang tua mereka sehingga sulit ditinggalkan. Kebiasaan seperti meminum ramuan (rorano) sebelum dan sesudah melahirkan yang diracik sendiri oleh dukun bayi, pijat, dan menghangatkan tubuh di dekat api atau yang di sebut baraho untuk mengembalikan kebugaran tubuh setelah bersalin yang sudah menjadi kebiasaan masyarakat setempat, semua perawatan tersebut hanya didapatkan di dukun bayi, oleh karena itu tidak mengherankan bila masyarakat masih tetap menggunakan jasa dukun bayi. 


\section{KEPUSTAKAAN}

Anike K. 2007. Kepercayaan ibu bersalin miskin tentang pertolongan persalinan oleh dukun studi kasus di wilayah puskesmas Dompu kota kecamatan Dompu kabupaten Dompu propinsi NTB. Tesis universitas Gadjahmada.

Astuti, P. Ana. 2013. Analisis alasan pemilihan penolong persalinan oleh ibu bersalin di kabupaten Semarang. Badan Pusat Statistik, BKKBN, Depkes RI \& ORC marco. 2007. Survey Demografi dan Kesehatan Indonesia (SDKI). Jakarta.

Badan Pusat Statistik. 2012. Kabupaten Halmahera Utara dalam angka 2012. Halmahera Utara.

Depkes RI. 2008. Pedoman Kemitraan Bidan Dengan Dukun. Jakarta: Depkes RI.

Dinas Kesehatan Propinsi Maluku Utara. 2012. Kasus kematian ibu masih tinggi. Maluku Utara.

Dinas Kesehatan Kabupaten Halut. 2012. Data kematian ibu dan bayi. Halmahera Utara.

Harrison, A. W., Rainer, Jr. R. K., Hochwarter, W.A., \& Thompson, K.R. 1997. Testing the self efficacyperformance linkage of social cognitive theory. Journal of social psychology, 137, no 1, 79-87.
Hermawati. 2012. Implementasi program kemitraan bidan dan dukun oleh bidan desa di kabupaten Buton propinsi Sulawesi Tenggara. Universitas Diponegoro. Semarang.

Maisya, B.I. 2006. Faktor-faktor Yang Berhubungan Dengan Pemanfaatan Dukun Sebagai penolong Persalinan Di Kabupaten Sukabumi. Universitas Indonesia, Depok.

Mayer, R. C., Davis, J. H., Schoorman, F. D. 1995. An integrative model of organizational trust. Academy of Management Review, No. 20, 709734.

Mesters, I., Wahl, S., \& Keulen K. M. V. 2014. Socio-Demographic, medical and social-cognitive correlates of physical activity behavior among older adults (45-70 years): a crosssectional study. BMC Public Health.

Notoatmodjo, S. 2010. Ilmu Perilaku Kesehatan. Rineka Cipta, Jakarta.

Nuraeni, S, Purnamawati D. 2012. Perilaku pertolongan persalinan oleh dukun bayi di kabupaten Karawang 2011. Unsoed, Purwokerto.

Profil Kesehatan Kabupaten Halut. 2012. Bidan dan Dukun. Halmahera Utara.

Riset Kesehatan Dasar. 2010. Strategi operasional turunkan angka kematian ibu. Jakarta. 
Santrock, J.W. 2010. Psikologi pendidikan (Edisi Kedua). Kencana. Jakarta.

Saputra, W. 2014. Arah dan strategi kebijakan penurunan angka kematian ibu (AKI), angka kematian bayi $(A K B)$ dan angka kematian balita (AKABA) di Indonesia.

Shoji, K., Bock, J., Cieslak, R., Zukowska, K., Luszczynska, A., \& Benight, C. C. 2014. cultivating secondary traumatic growth among healthcare workers: the role of social support and self efficacy. Journal of clinical psychology, Vol. 70, no. 9, 831-846.

Triratnawati, A. 1995. Pendekatan Antropologi dalam penempatan Bidan di Desa. Jurnal Jaringan Epidemiologi Nasional, Vol 1: 7-9. 